Volume 4, Issue 1 (Winter 2012)

\title{
Archival Note: Gerhard Morell and the Last Acquisitions of Christian Ludwig of Mecklenburg-Schwerin
}

Gero Seelig

Recommended Citation:

Gero Seelig, "Archival Note: Gerhard Morell and the Last Acquisitions of Christian Ludwig of Mecklenburg-Schwerin," JHNA 4:1 (Winter 2012), DOI: 10.5092/jhna.2012.4.1.4

Available at https://jhna.org/articles/archival-note-gerhard-morell-last-acquisitions-christian-ludwig-of-mecklenburg-schwerin/

Published by Historians of Netherlandish Art: https://hnanews.org/

Republication Guidelines: https://jhna.org/republication-guidelines/

Notes: This PDF is provided for reference purposes only and may not contain all the functionality or features of the original, online publication. This is a revised PDF that may contain different page numbers from the previous version. Use electronic searching to locate passages. This PDF provides paragraph numbers as well as page numbers for citation purposes.

ISSN: 1949-9833 


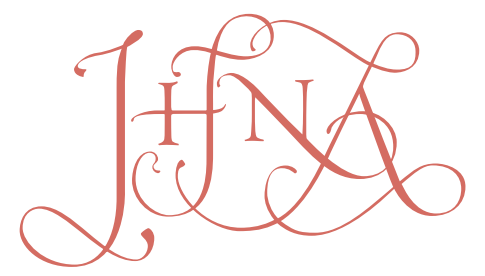

\section{ARCHIVAL NOTE: GERHARD MORELL AND THE LAST ACQUISITIONS OF CHRISTIAN LUDWIG OF MECKLENBURG-SCHWERIN}

\section{Gero Seelig}

The Sentry by Carel Fabritius was bought by Duke Christian Ludwig for the Schwerin collection in the last of his many painting acquisitions. Its purchase appears in an invoice of August 2, 1755, submitted to the duke by the art dealer Gerhard Morell, subsequently the director of the royal paintings collection in Copenhagen. The same invoice lists numerous other works in the Schwerin collection, and annotations show that the duke's son, Hereditary Prince Friedrich, was closely involved in these transactions. 10.5092/jhna.2012.4.1.4

The circumstances and precise date of acquisition of the Sentry by Carel Fabritius (fig. 1) for the Schwerin collections have long been unanswered questions. ${ }^{1}$ The painting is easily recognizable in inventories due to its unusual iconography, typically described as a soldier or hunter cleaning his rifle. It was conspicuously absent from the inventory of the paintings at Schwerin castle in $1752 .{ }^{2}$ Instead, it first turns up as the work of an anonymous artist in the earliest printed catalogue in $1792 .^{3}$

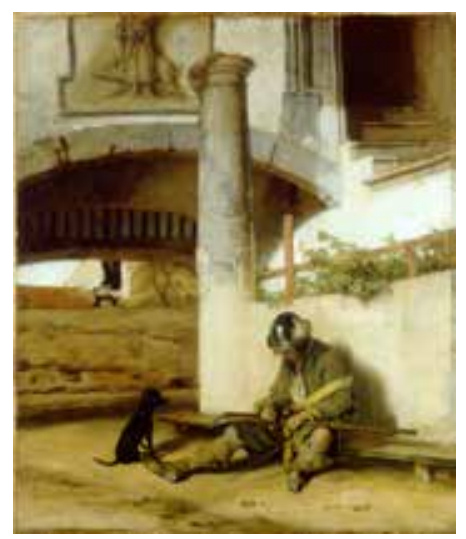

Fig. 1 Carel Fabritius, The Sentry, 1654, oil on canvas, $67.5 \times 58 \mathrm{~cm}$, Staatliches Museum Schwerin, inv. no. G 2477 (artwork in the public domain)

Only recently has Volker Manuth provided one of the missing links in the Sentry's provenance, by identifying it under Rembrandt's name in the Amsterdam sale of Gerhard Michael Jabach's collection on October 16, 1753. Though Jabach had resided in Livorno, the collection was auctioned off in Amsterdam. There the Sentry was sold to "Winter" for 32 guilders, 10 stuivers, as revealed in the annotated auction catalogue in the Rijksbureau voor Kusthistorische Docu- 
mentatie (RKD). ${ }^{4}$ Manuth has plausibly identified the buyer as the painter-dealer Hendrick de Winter (1717-1790), who had connections to northern Germany. Manuth's hypotheses now are confirmed by a document from the Schwerin archive, a list of paintings sold by the Hamburg art dealer Gerhard Morell (ca. 1710-1771) to Duke Christian Ludwig during the last year of the prince's life (fig. 2). Dating from August 2, 1755, the list records the entry as "no. 10: Gerbr. v. Eekhout. Ein sein Gewehr puzender Soldat - 60 Rthlr" (Gerbrand van den Eeckhout. A soldier cleaning his rifle - 60 Reichstaler). Though the painting was thought to be by Rembrandt in the 1753 sale, a copyist, probably de Winter himself, had by then identified the painter as Gerbrand van den Eeckhout, whose name is noted on the back of a watercolor copy of the Sentry in a private collection. $^{5}$

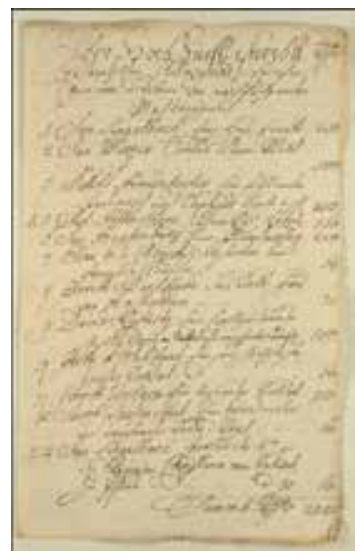

Fig. 2 Gerhard Morell, Invoice to Christian Ludwig, August 2, 1755, first page, Landesarchiv Schwerin.

3 Morell seems to have transacted more business with de Winter. In his forthcoming study of Gerhard Morell, who subsequently became gallery director for the Danish king, Michael North relates that in a 1759 sale in Copenhagen, paintings bought by one "De Winter" were later sold to the king by Morell. It seems likely that this is the same de Winter from whom Morell had earlier received the Fabritius painting. Both dealers wanted to profit from their transactions, and the Sentry almost quadrupled in price between 1753, when it was bought by de Winter for the low price of 32 guilders (about 16 Reichstaler), and 1755, when sold for 60 Reichstaler by Morell to the duke in Schwerin. The latter sum was still remarkably low for such a masterpiece.

4 The Schwerin list holds further significance, containing some of the best pieces of the collection, among them Gerard ter Borch's Young Man Reading, Jan Asselijn's large Winter Landscape (lost in 1945), and, of course, Fabritius's Sentry. ${ }^{6}$ These three paintings, whose earlier provenances indicate the dealer's acquisition price, are especially illuminating for the study of the eighteenth-century art market. The three paintings were bought at auctions in the Netherlands just before Morell sold them to Christian Ludwig in Schwerin. In all three cases, Morell charged prices significantly higher than he himself hadpaid. Such profit margins may not be surprising, but this transaction is the first such example to be documented in Schwerin.

Jan Asselijn's Winter Landscape (fig. 3) is recorded on October 21, 1754, in Amsterdam in the sale of J. Tonnemann, ${ }^{7}$ where it appears as lot 27: "Een extraordinair schoon stuk van Asselyn, alias Crabbetje, verbeeldt een Winter daar eenige Jongens malkander met Sneeuwballen gooyen; zeer Natuurlyk geschildert, hoog 27 1/2, breet 32 duim" (An extraordinarily beautiful piece by Asselijn, i.e., Crabbetje, a winter scene where some boys throw snowballs at each other; painted very true 
to life, height $65.9 \mathrm{~cm}$, width $76.7 \mathrm{~cm}$ ). In the copy of the auction catalogue kept in the RKD in The Hague, the manuscript annotation to this lot reads: “Morel - 135," establishing that Morell himself bought the Asselijn less than a year before selling it to Schwerin. The sale price of 135 guilders comes to a little over 65 Reichstaler. In selling it to the duke for 100 Reichstaler Morell made a profit of 35 Reichstaler or 70 guilders.

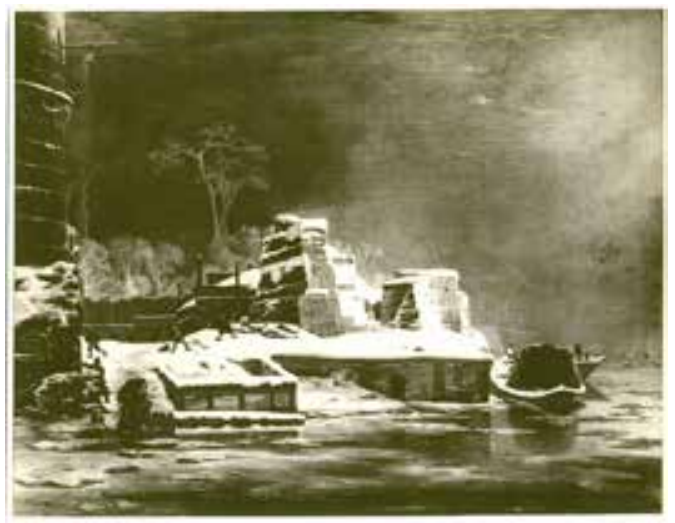

Fig. 3 Jan Asselijn, Winter Landscape, oil on canvas, 66.8 x 81.5 $\mathrm{cm}$, Staatliches Museum Schwerin, lost in 1945.

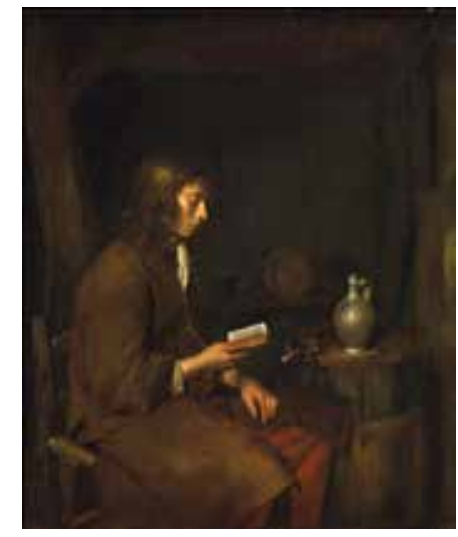

Fig. 4 Gerard ter Borch, Reading Young Man, oil on panel, $43.5 \times 36.5 \mathrm{~cm}$, Staatliches Museum Schwerin, inv. no. $G 80$ (artwork in the public domain)

Only four days after securing the Asselijn painting, Morell also acquired Gerard ter Borch's Young Man Reading (fig. 4) as part of a sale in Leiden, probably the estate of Catharina Adriana de la Court. The ter Borch was sold to Morell on October 25, 1754, as lot 25 for 140 guilders, ${ }^{8}$ equalingabout 70 Reichstaler. As recorded on Morell's invoice to the duke, the painting cost more than twice that amount-150 Reichstaler-giving the dealer a profit of 80 Reichstaler.

Christian Ludwig had had a long-standing relationship with Morell. Their earliest documented exchange concerns the dealer's delivery of a "Mahlerey von Fyt worauf ein todtes Reh" (painting by Fyt of a dead deer) for 15 Reichstaler in March 1745. ${ }^{9}$ Though letters are extant only for this and the following year, they establish that the duke often bought from Morell, not only paintings but also sculptures, illustrated books, and other luxury goods. As I have mentioned elsewhere, Morell was only one of the dealers in contact with the duke, which led to significant tensions among the dealers. In fact, complaints about Morell allegedly selling fakes had already started in 1742, three years before his first documented contact with the duke. ${ }^{10}$ Apparently, these rumors did not prevent the collector from using the dealer's services, as evidenced by correspondence between Morell and the court in the Schwerin archives. Surprisingly, though, there are very few works that can be positively linked to a provenance from Morell. In 1746 the dealer wrote to the duke about "die Maria Magdalena von Jordans so ich die Gnade gehabt habe Ew. HochFürstl. Durchl. zu verkaufen" (the Mary Magdalene by Jordaens that I was graced to sell to Your Highness), but there seems to be no other trace of this work, unless it is identical to the only Jacob Jordaens extant in Schwerin, the enigmatic Night Vision. ${ }^{11}$ A painting of dead birds by Willem van Aelst bought for 300 Reichstaler by the duke in 1745 can tentatively be identified as the largest van Aelst in Schwerin, the Dead Roosters of 1676. ${ }^{12}$ In spite of the extensive correspondence between Morell and the court about auctions and art works, until now no other works have been identified as coming to Schwerin via the Hamburg dealer. 
To return to the year 1755, Morell's last invoice highlights the fact that Christian Ludwig spent lavishly on art and artifacts until the very end of his life. In fact, the list has remained unknown so long precisely because it is filed among the unpaid bills Duke Friedrich had to grapple with when assuming power after his father died on May 30, 1756. It added almost 2,000 to the over 17,000 Reichstaler Christian Ludwig had been due to pay from his private funds (the state itself, on a larger scale, was in similar straights). These last acquisitions, then, appear only in the files of Friedrich, a notorious cost-cutter who, after coming to power, acquired not one single documented painting from anyone other than his court artists. ${ }^{13}$ Because of Duke Friedrich's tight spending policy and lack of interest in painting, one would hardly expect to find documentation of lavish spending in the files of his private funds.

9 Therefore, it is highly interesting to see that Friedrich, almost from the start, was closely involved in this last transaction between his father and Morell. Apart from the final invoice reproduced at the end of this article, a preliminary list dated July 31, 1755 is preserved in the archive. It, too, is written in Morell's hand and differs from the final invoice in a number of places. At the close of the document, Morell states that this preliminary list records the initial selection the duke made without the prince being present. After the prince returned from Hamburg, the duke decided to give back six of the pieces selected and, following the wishes of the prince, to include six others. ${ }^{14}$ Here is an instance where Friedrich's direct influence on his father's collection becomes apparent. The alteration is remarkably small, concerning only the exchange of four landscapes (by Nicolaes Berchem and Jacob de Heusch) and two peasant genre paintings (by David Teniers and David Rijckaert) ${ }^{15}$ for two other landscapes (by Jan [probably mistaken for Dirck] van Bergen), two animal pieces (by Jan Weenix and Melchior d'Hondecoeter [fig. 5]), a marine painting by Simon de Vlieger (fig. 6), and a cut crucifix by "Francis." ${ }^{16}$ There is no way to ascertain the originality and quality of the rejected paintings, except for the prices, which add up to 730 Reichstaler, as against 1,250 for the new additions. Considering the quality of the newly chosen pieces, so far as we can identify them, the change was probably for the better.

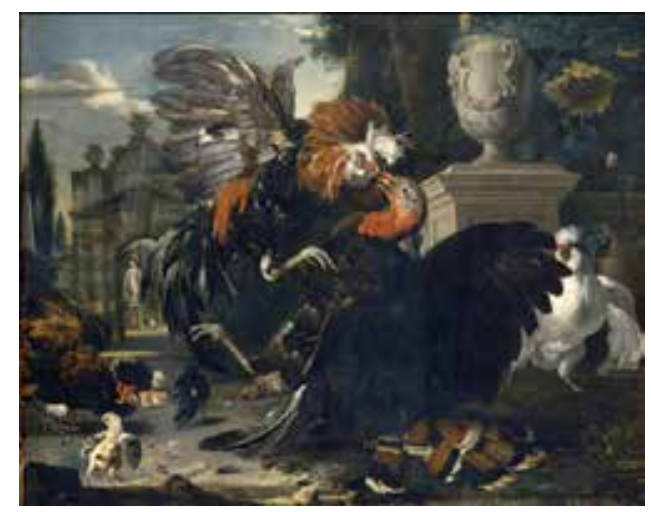

Fig. 5 Melchior d'Hondecoeter, Turkey and Rooster Fighting, 1668 , oil on canvas, $102 \times 128 \mathrm{~cm}$, Staatliches Museum Schwerin, inv. no. $\mathrm{G} 55$ (artwork in the public domain)

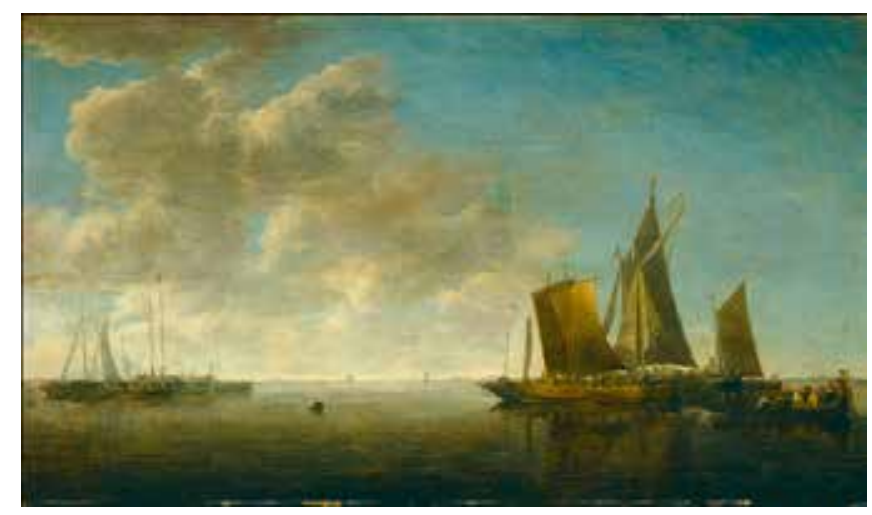

Fig. 6 Simon de Vlieger, Calm Sea, oil on panel, $52 \times 89 \mathrm{~cm}$, Staatliches Museum Schwerin, inv. no. G 123 (artwork in the public domain)

In the light of these documents, we can rule out the notion proposed by some that because of the duke's impaired eyesight, it was Friedrich who was largely responsible for all of Christian Ludwig's 
art acquisitions during the last years of the latter's life. Furthermore, it cannot have been the onset of the Seven Years' War that forced Friedrich to stop buying art. While Friedrich came to power at the end of May 1756, the war started in August of that year and Mecklenburg only became engaged in it when Friedrich joined the Reichsexekution (imperial intervention) against Prussia in January 1757. These sweeping historical events cannot account for his abandonment of his father's example as a lavish collector, because they post-date Friedrich's succession to the throne. It seems far more likely that his well-known religious austerity, ${ }^{17}$ on top of his clear insight into his unstable financial situation, made him adverse to luxury expenditures. While his father was alive, Friedrich was unable to do much more than influence the quality of the selections. Remarkably, in so doing, he acquired the two most expensive pieces, the large decorative Jan Weenix and the beautiful de Vlieger, thereby increasing the sum owed from 2,500 to 3,000 Reichstaler.

11 In fairness to Morell, I should point out that in the final invoice the sum of 3,220 Reichstaler was rounded down to 3,000, reducing the total by almost 7 percent. Some kind of reduction was probably an accepted common courtesy between dealer and client. The preliminary list did not include the price reduction, but Morell included a few items without charge. Nevertheless, he carefully totaled their costs, amounting to 130 Reichstaler. ${ }^{18}$ Furthermore, he intended to charge only 70 Reichstaler for a pastel by Teniers allegedly worth $100 .{ }^{19}$ In an interesting twist, the reduced Teniers and the two (free) de Heusch landscapes were among the pieces later on rejected by the prince. The painting by Jan Brueghel (fig. 7), on the other hand, was entered in the later list with a price of 50 Reichstaler, an extremely low price for this sought-after master. Perhaps both dealer and clients were not convinced of its authenticity (but still left it on the list). Such doubts continued into the nineteenth and twentieth centuries. ${ }^{20}$ Luckily, the painting on copper was acquired and retained in spite of these doubts and is today one of three authentic works by Jan Brueghel the Elder in Schwerin. ${ }^{21}$

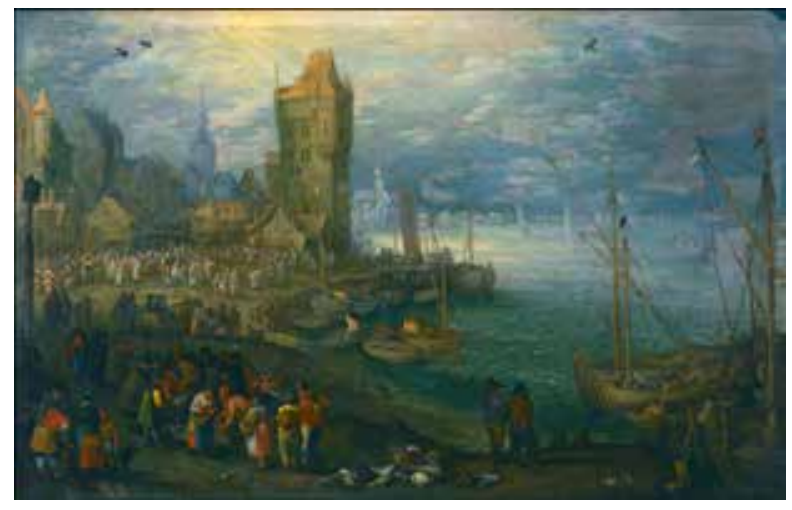

Fig. 7 Jan Brueghel the Elder, Fish Market in Front of a City on the Water, oil on copper, $18 \times 27.5 \mathrm{~cm}$, Staatliches Museum Schwerin, inv. no. G 2343 (artwork in the public domain)

12 Terms of payment as well as price were both typically negotiated, and as a further concession to his customers, Morell agreed to receive payment in installments over a period of fourteen months. This method was used quite often, even for much smaller sums, but in this case it can also be considered as a particular risk taken by the dealer. In the summer of 1755, the health of Christian Ludwig, at seventy-two years of age, must already have been failing. Most likely his death in May 1756 came as no surprise, not even to the dealer who had been in Schwerin in the summer of 1755 to complete his sale. He must have been convinced of Friedrich's compliance with the deal when he made it. In the end, Morell's calculation turned out to be correct, and he received 
payment in full, albeit half a year later than the contract stipulated. ${ }^{22}$ Morell was unusual in his willingness to take this risk; other partners of Christian Ludwig, less trusting, strictly insisted on direct payment, if they were in a position to do so. The famed flower painter Jan van Huysum, for instance, rejected the duke's request to receive a particular painting in Schwerin on approval before buying it. Already in 1733 van Huysum referred to the duke's possible death, which could jeopardize future installments, and, therefore, refused such a deal. ${ }^{23}$

13 The list of paintings Gerhard Morell sold to Duke Christian Ludwig, preserved in the Schwerin archives, constitutes a valuable source of information on several aspects of the Schwerin painting collection. In addition to evidence of the provenance and acquisition date of a number of important works, it indicates the methods of both the dealer and the collector in negotiating their deals. Both sides, it turns out, bargained hard, and the dealer took a considerable risk in selling to the aging duke. It ended well for Morell, but in recording his last sale to the Schwerin court, the 1755 invoice also attests to the last of Christian Ludwig's many art acquisitions, including Schwerin's precious painting, Fabritius's Sentry.

14 Following is the full text of Morell's invoice to the duke, with identifications of the particular paintings in the notes. ${ }^{24}$

Ihro Hoch Fürstl. Durchll. Erhandelten Allergnäd. Empfingen und Belieben vor nachfolgenden Mahlereyen.

1 Jan Lingelbach. Eine Heu Erndte - Rthlr. $250^{25}$

2 Jan Weenix. Todtes Klein Wild ms.f. - 500

3 Melch. Hondekoeter. Ein fechtender Indiansch und Teutscher Hahn u.s.f. ${ }^{26}-250$ (fig. 5)

4.5 Joh. Hinr. Roos. Zahme Vieh Heerden ${ }^{27}-160$

6 Jan Hugtenburg. Eine Plünderung - 250

7 Elias v.d. Broeck. Insecten und Frembde Kräuter ${ }^{28}-60$ (fig. 8)

8 Gerritt Berkheyde. Das Stadt-Haus van Amsterdam ${ }^{29}-75$

9 David Rykarts. Eine fröhliche Bauer Gesellschaftt an Statt Dieses ein geschnitten Crucifix - 150

10 Gerbr. v. Eekhout. Ein sein Gewehr puzender Soldat ${ }^{30}-60$ (fig. 1)

11 Gerritt Terburg. Ein lesender Soldat ${ }^{31}-150$ (fig. 4)

12 Jacob Toorenvliet. Ein trinckender und rauchender Bauer-Vogt-60 ${ }^{32}$ (fig. 9)

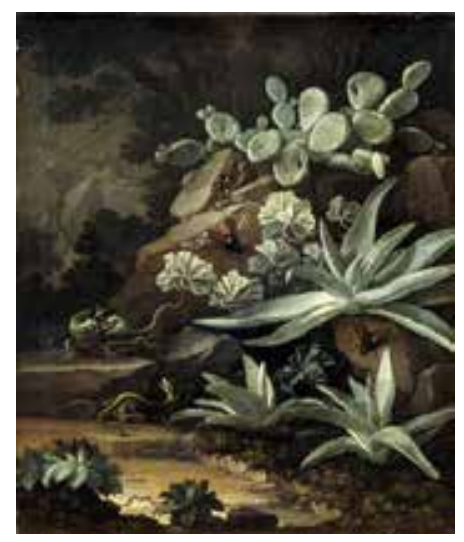

Fig. 8 Elias van den Broeck, Cactuses and Lizards, oil on canvas, $62 \times 53 \mathrm{~cm}$, Staatliches Museum Schwerin, inv. no. G 73 (artwork in the public domain)

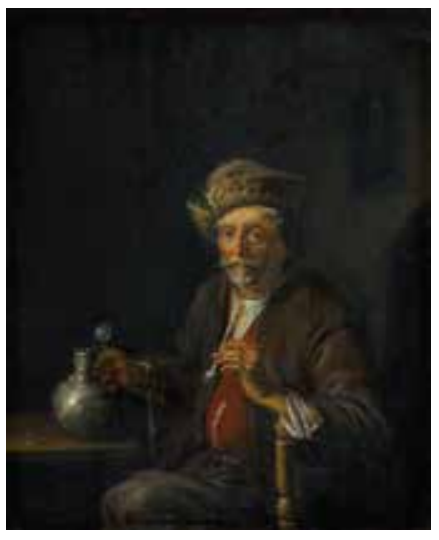

Fig. 9 Jacob Toorenvliet, The Smoker, oil on panel, $36.5 \mathrm{x}$ $29.8 \mathrm{~cm}$, Staatliches Museum Schwerin, inv. no. G 2291 (artwork in the public domain) 
13.14 Jan Lingelbach. Carolus der 5te Die Königin Christina van Schweden zu Pferde à $30^{33}-60$ Summa Rthlr 2025

[verso] Transport Rthlr 2025

15.16. Isaac Moucheron Sehr angenehme Landschafften à $100^{34}-200$

17 Egbert v.d. Poel Ein brennendes Dorf bey Nacht ${ }^{35}-80$ (fig. 10)

18 Andr. Both. Ein Italiänisches Wirths Hauß mit Maul-Esel Treiben u.s.f. -150

19 Fried. Moucheron. Gebirgigte Landschaft mit einer Vieh Trift Staffiret van Jan

Lingelbach ${ }^{36}-75$ (fig. 11)

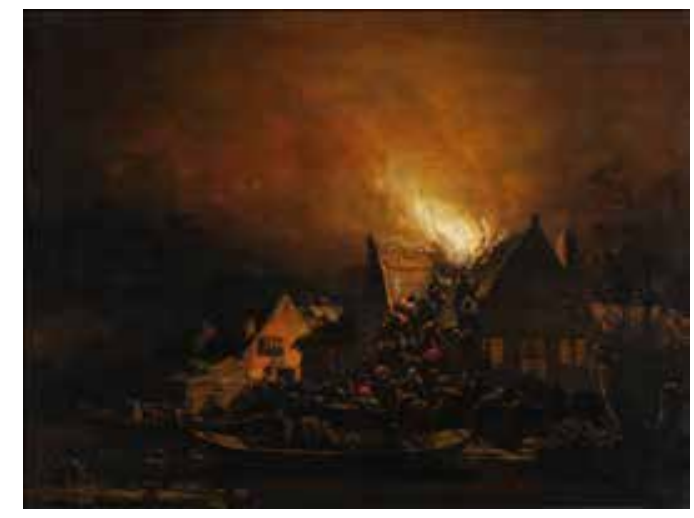

Fig. 10 Egbert Lievensz. van der Poel, Cottage Burning at Night, oil on panel, 46.9 × $62 \mathrm{~cm}$, Staatliches Museum Schwerin, inv. no. $\mathrm{G} 374$ (artwork in the public domain)

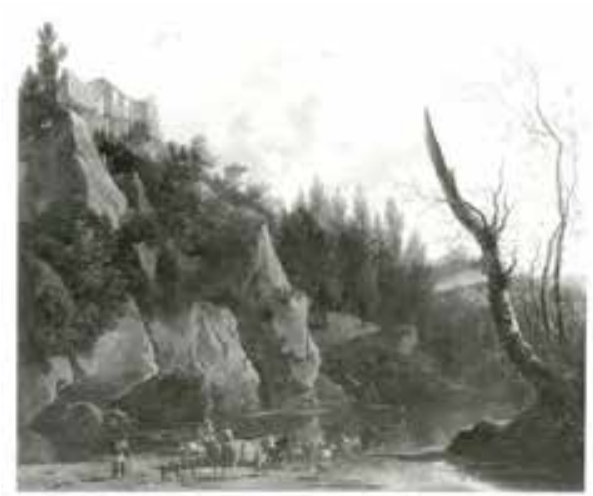

Fig. 11 Frederick de Moucheron, Italian Landscape with Cattle, oil on canvas, $68 \times 80 \mathrm{~cm}$, Herzog Anton Ulrich-Museum, Braunschweig, inv. no. 391 (artwork in the public domain)

20 Matth. Willmann. Discipul van Anth. v. Dyk Die Entführung der Europa ${ }^{37}-150$

21 Jan Asselyn alias Crabbetje. Ein Winter Stück mit einer Holländischen Ziegel Brennerey ${ }^{38}-100$ (fig. 3)

22 Jan Brügel. Ein See Hafen mit sehr vielen Figuren ${ }^{39}-50$ (fig. 7)

$23 \mathrm{Sim}$. de Vlieger. Ein Wasser Gesicht von der Maas mit sehr vielen Figuren ${ }^{40}-300$ (fig. 6)

24.25. Jan v. Bergen. Zahmes Vieh ${ }^{41}$ à $25-50$

26 Jan Hacker. Landschaftt mit Römischen Ruderibus -40

Summa Rthlr 3220

Schwerin den 2ten Aug. 1755

unterthänigster Gerhard Morell

[Annotation:] Vorstehende 3220 r. sind behandelt zu 3000 rthl. in Golde, und ist dabey gnädigst versprochen worden, daß solche summa termins-weise, und zwar auf nechstkomenden Michaelis dieses jeztlauffenden 1755 Jahres - 1000 rthl., auf Weynachten ej. an. 500 rth. auf Ostern 1756 wieder - 500 rth. auf Johannis 1756 noch - 500 rth. und endl. auf Michaelis - 1756 die lezten 500 rthl. bezahlet werden sollen. Schwerin d. 2ten Aug. 1755. [Paraphe:] CLHZM

\section{Acknowledgments}

I am indebted to the anonymous reader of JHNA for his or her suggestions concerning the struc- 
ture of the article. Chrysanthi Fairchild and especially Lisa Pincus have been immensely helpful in improving language and logic. Translations are mine.

Gero Seelig has been curator of paintings at the Staatliches Museum Schwerin since 2001. He has published two parts of a planned six-part catalogue of the Dutch and Flemish paintings in Schwerin and has mounted exhibitions on Carel Fabritius and Nicolaes Berchem. He is currently preparing an exhibition on Abraham Bloemaert. Seelig is cofounder of the Arbeitskreis Niederländische Kunst- und Kulturgeschichte, which focuses on the study of Dutch and Flemish art in Germany. Apart from painting, he has published on German printmaking of the fifteenth and sixteenth centuries and on the history of collecting.

\section{List of Illustrations}

Fig. 1 Carel Fabritius, The Sentry, 1654, oil on canvas, 67.5 x $58 \mathrm{~cm}$, Staatliches Museum Schwerin, inv. no. G 2477 (artwork in the public domain)

Fig. 2 Gerhard Morell, Invoice to Christian Ludwig, August 2, 1755, first page, Landesarchiv Schwerin.

Fig. 3 Jan Asselijn, Winter Landscape, oil on canvas, 66.8 x $81.5 \mathrm{~cm}$, Staatliches Museum Schwerin, lost in 1945.

Fig. 4 Gerard ter Borch, Reading Young Man, oil on panel, 43.5 x $36.5 \mathrm{~cm}$, Staatliches Museum Schwerin, inv. no. G 80 (artwork in the public domain)

Fig. 5 Melchior d'Hondecoeter, Turkey and Rooster Fighting, 1668, oil on canvas, 102 x 128 cm, Staatliches Museum Schwerin, inv. no. G 55 (artwork in the public domain)

Fig. 6 Simon de Vlieger, Calm Sea, oil on panel, 52 x $89 \mathrm{~cm}$, Staatliches Museum Schwerin, inv. no. G 123 (artwork in the public domain)

Fig. 7 Jan Brueghel the Elder, Fish Market in Front of a City on the Water, oil on copper, $18 \times 27.5$ $\mathrm{cm}$, Staatliches Museum Schwerin, inv. no. G 2343 (artwork in the public domain)

Fig. 8 Elias van den Broeck, Cactuses and Lizards, oil on canvas, 62 x $53 \mathrm{~cm}$, Staatliches Museum Schwerin, inv. no. G 73 (artwork in the public domain)

Fig. 9 Jacob Toorenvliet, The Smoker, oil on panel, 36.5 x $29.8 \mathrm{~cm}$, Staatliches Museum Schwerin, inv. no. G 2291 (artwork in the public domain)

Fig. 10 Egbert Lievensz. van der Poel, Cottage Burning at Night, oil on panel, $46.9 \times 62 \mathrm{~cm}$, Staatliches Museum Schwerin, inv. no. G 374 (artwork in the public domain)

Fig. 11 Frederick de Moucheron, Italian Landscape with Cattle, oil on canvas, 68 x $80 \mathrm{~cm}$, Herzog Anton Ulrich-Museum, Braunschweig, inv. no. 391 (artwork in the public domain) 
${ }^{1}$ The most relevant literature on the painting includes: C. Brown, Carel Fabritius: Complete Edition with a "Catalogue Raisonné" (Oxford: Phaidon, 1981), no. 8; F. J. Duparc, G. Seelig, and A. van Suchtelen, Carel Fabritius 1622-1654 (The Hague: Mauritshuis; Schwerin: Staatliches Museum, 2004-5), no. 12; L. Pincus, Experiment in Seventeenth-century Dutch Painting: The Art of Carel Fabritius (Ann Arbor, Mich.: UMI, 2005), 100-61; G. Seelig, [Review] "Carel Fabritius: Symposium des Niederländischen Instituts für Kunstgeschichte (RKD) und des Mauritshuis, Den Haag, 1.-2. Dezember 2004," Kunstchronik 58 (2005): 6-11, esp. p. 7; V. Manuth, "A Note on Carel Fabritius's Sentry in Schwerin," Oud Holland 119 (2006): 99-109; and G. Seelig, Die holländische Genremalerei in Schwerin (Petersberg: Imhof, 2010), 89-94.

${ }^{2}$ Inventarium über die sämtlichen Zimmer, Mobilien und Gemählde auf dem Herzogl. Schlosse zu Schwerin, aufgenommen Anno 1752 Mense Januar von Notar Cuno Henning Schroeder, manuscript in Landeshauptarchiv, Schwerin, 2.26-2 Hofmarschallamt mit Hofbauamt [1753-1918/20], no. 1849. The painting's early provenance may be the notice of "een stuc schilderij, gedaen door fabritius, afbeeldende een jager" (a piece of painting, by Fabritius, depicting a hunter) in the brewery called "De Wereld" in Leiden in 1677 and 1678; see Brown, Fabritius, appendix A, doc. 44 and 45, December 5, 1677, and April 19, 1678.

${ }^{3}$ G. Groth, Verzeichniß der Gemälde in der Herzoglichen Gallerie (Schwerin: Bärensprung, 1792), [no. 396], p. 57, room L, wall I, no. 1 (as by “Meister AS"). In the eighteenth century, the signature was not visible.

${ }^{4}$ Manuth, "A Note," 101-2. His fig. 3 shows the catalogue entry for the Sentry. See F. Lugt, Répertoire des Catalogues de Ventes Publiques, vol. 1 (The Hague: Nijhoff, 1938), no. 816, lot 37. http:// dx.doi.org/10.1163/187501706X00375

${ }^{5}$ Watercolor on paper, 31.5 x $27.7 \mathrm{~cm}$, Six collection, Amsterdam; see Manuth, "A Note," 100-1 (with ill). The watercolor was sold in 1756 with the possessions of the duc de Tallard in Paris (see ibid., 108, n. 10; for the sale see Lugt, Répertoire, no. 910). Therefore it was most likely executed between 1753 and 1755. http://dx.doi.org/10.1163/187501706X00375

${ }^{6}$ Thirteen paintings on the list can be positively identified and another eight tentatively. See the notes to the full text of the document at the end of this article.

${ }^{7}$ Lugt, Répertoire, no. 845.

${ }^{8}$ See J. Giltaij, Senses and Sins: Dutch Painters of Daily Life in the Seventeenth Century (Rotterdam: Museum Boijmans Van Beuningen; Frankfurt am Main: Städel Museum, 2004-5), no. 48. Lugt, Répertoire, no. 846.

${ }^{9}$ Landeshauptarchiv, Schwerin, 2.12-1/26, Acta aulica, VI. Angebote und Erwerbungen, no. 101 (Gerhard Morell), fol. 3, 9.

${ }^{10}$ See Seelig, Genremalerei, 13-14.

${ }^{11}$ Inv. G 161, Jacob Jordaens, Night Vision, oil on canvas, 133 x 146.5 cm; G. Seelig, Jan Brueghels Antwerpen: Die flämischen Gemälde in Schwerin (Schwerin: Staatliches Museum, 2003), 138. ${ }^{12}$ Inv. G 405, Willem van Aelst, Dead Roosters. The only description of the piece sold by Morell is in a letter of January 14, 1746, in which he acknowledges his receipt of payment and where the painting is described as a "piece with birds" (Feder=Vieh=Stück). Any one of four paintings by van Aelst with dead birds in Schwerin could fit that description. The only further clue to the identity of the Morell painting is the fact that it was compared to a work by Weenix, which was probably the one going to Paris in 1807; see G. Seelig, "Paris und retour-Die Schweriner Gemäldesammlung 1807-1816," in Unter Napoleons Adler: Mecklenburg in der Franzosenzeit, ed. M. Manke and E. Münch (Lübeck: Schmidt-Römhild, 2009), 313-62, here p. 344, no. 69, not 
identified with an extant painting. Since the Weenix measured circa $110 \times 95 \mathrm{~cm}$ and the Dead Roosters is the only work by van Aelst of similar size in Schwerin, the others being much smaller, the Morell painting is probably G 405.

${ }^{13}$ For his acquisitions as hereditary prince, most notably his dealings with Jean-Baptiste Oudry, see C. Frank, "Pictorial Relations: New Evidence on Jean-Baptiste Oudry and the Court of Mecklenburg-Schwerin," in Oudry's Painted Menagerie: Portraits of Exotic Animals in Eighteenth-Century Europe, ed. M. Morton (Los Angeles: J. Paul Getty Museum, 2007), 31-57; E. Korthals Altes, “The Art Tour of Friedrich of Mecklenburg-Schwerin," Simiolus 31 (2004-5): 216-50.

14 "EW: Hoch Fürstl Durchl. So wie dieses war die eygene Wahl Ihro Hoch Fürstl. Durchl. des Herzogs in Abwesenheit Ihro Durchl. des ErbPrinzen, nach deren ZurückKunftt von Hamburg aber haben S.mus auf Dero bezeigten Wünschen No: 2. 3. 9. 22. 23. 24. zurück gegeben[,] in der Allergnädigst unter Zeichneten veraccordirten Rechnung die No 2.3. 9 das Crucifix durch Franeis geschnitten 23. 24. 25 aber nach des Erb=Prinzen Wahl zurück genommen, und die Summa biß $3000 \mathrm{rl}$. vermehret, der accord ist von $\mathrm{H}$. Hof=Rath Roland angefüget, und daß gleichfals gnädigst unterzeichnete Duplicat hat der Hf. Secret: Cöppen in Verwahrung dieses dienet zum Beweiß das der Handel mit S.mi des Erb=Prinzen Vorwissen und Genehmhaltung geschehen. Swerin den 31. Jul: 1755 unterthanigster Gerhard Morell.':Landeshauptarchiv, Schwerin, 2.121/26 Acta aulica, II. Etat- und Rechnungswesen, Nr. 29a [no page numbering].

${ }^{15}$ The rejected paintings are listed as: [nos.] 2.3 Zwey Stück van Nicolaus Berghem Pferde - à 200 - 400, [no.] 9 David Rykarts. Eine Bauer Gesellschaftt - 150, [no.] 22 David Teniers. Eine Bauer Gesellschafft Pastel 100 nur angerechnet. 70, [nos.] 23.24. Zwey Jacob de Heus. Angenehme Landschaftten - à 40. - 80 .

${ }^{16}$ Today, there is no crucifix in the collections that answers to this description. The artist meant may or may not have been the ivory cutter Francis van Bossuit (1635-1692), known mostly for reliefs. My thanks to Karin Annette Möller for this suggestion.

${ }^{17}$ See F. Wigger, "Aus dem Leben Herzog Friedrichs des Frommen bis zu seinem Regierungsantritt," Jahrbücher des Vereins für mecklenburgische Geschichte und Alterthumskunde 45 (1880): 53-176.

${ }^{18}$ The pictures not to be charged for are noted as: [Nos.] 23.24. Zwey Jacob de Heus. Angenehme Landschaftten - à 40. - 80 [Rthlr.]. [No.] 25 Jan Brügel Kleiner See=Strand mit sehr vielen Figuren - 50.Summa Rthlr. 130.

${ }^{19}$ [No.] 22 David Teniers. Eine Bauer Gesellschafft Pastel 100 nur angerechnet. 70 [Rthlr.].

${ }^{20}$ Seelig, Brueghels Antwerpen, 129.

${ }^{21} \mathrm{G} 2343$, Jan Brueghel the Elder, Fish Market in Front of a City on the Water, oil on copper, 18 x $27.5 \mathrm{~cm}$. See the collection catalogue, Seelig, Brueghels Antwerpen, 38-39 and 129-30, where I voiced my doubts about the authenticity of two other paintings ( $G$ 8, copy after Pieter Bruegel's Predication of Saint John; and G 163, Pan and Syrinx) in the catalogue entries but was unable to convince the editor to allow me to change the incorrect attributions.

${ }^{22}$ Only on March 20,1757, did Morell acknowledge receipt of the open sum of 1,500 Reichstaler, which should have been paid in installments of 500 in the spring, summer, and fall of 1756 (Ostern, Johanni, Michaeli). Morell had received the first two installments, 1,000 Reichstaler due in the fall of 1755 and 500 due at Christmas, on October 14, 1755, and February 18, 1756, when Christian Ludwig was still alive. (The receipts are also in: Landeshauptarchiv Schwerin, 2.12-1/26 Acta aulica, II. Etat- und Rechnungswesen, Nr. 29a [no page numbers].)

${ }^{23}$ Landeshauptarchiv Schwerin, 2.12-1/26 Acta aulica, VI. Angebote und Erwerbungen, Nr. 65 (J. 
N. van Haften), fol. 46-47, Aug. 21, 1733, van Haften from The Hague to the duke: “ . . das die Stücken vorher übersandt Würden, ist Vergeblich gewehsen Ihne [i.e. van Huysum] Zu proponiren, $\mathrm{Zu}$ mahlen Er, auff die Von Ihro Durchleücht so raisonnable Termins Weiße beZahlung nicht hat resolviren wollen, noch Können; sonderen mit alle höffelichkeit solches sich verbehten, und dabey erwehnt, das durch Sterbfälle bey dergeleichen Handlung viele Weitläuffigkaiten würden vorfallen."

${ }^{24}$ Landeshauptarchiv Schwerin, 2.12-1/26 Acta aulica, II. Etat- und Rechnungswesen, Nr. 29a [without pagination].

${ }^{25}$ Possibly G 145, Johannes Lingelbach, Hay Harvest, oil on canvas, 62 x $78.5 \mathrm{~cm}$.

${ }^{26}$ G 55, Melchior d'Hondecoeter, Turkey and Rooster Fighting, 1668, oil on canvas, 102 x $128 \mathrm{~cm}$.

${ }^{27}$ Possibly G 610, Johann Heinrich Roos, Roman Landscape with Cattle and Family of Herders, 1684, oil on canvas, 50.8 x 63 cm; G 611, Johann Heinrich Roos, Roman Landscape with Cattle, 1684 , oil on canvas, $50.8 \times 63.6 \mathrm{~cm}$.

${ }^{28} \mathrm{G} 73$, Elias van den Broeck, Cactuses and Lizards, oil on canvas, $62 \times 53 \mathrm{~cm}$.

${ }^{29}$ Most probably G 399, Gerrit Berckheyde, The Dam Square in Amsterdam, 1665, oil on canvas, $60 \times 53 \mathrm{~cm}$.

${ }^{30} \mathrm{G} 2477$, Carel Fabritius, The Sentry, oil on canvas, $67.5 \times 58 \mathrm{~cm}$.

${ }^{31}$ G 80, Gerard ter Borch, Reading Young Man, oil on panel, $43.5 \times 36.5 \mathrm{~cm}$. In the earlier list mentioned above, the work is referred to as Ein betender Soldat (a praying soldier).

${ }^{32} \mathrm{G} 2291$, Jacob Toorenvliet, The Smoker, oil on panel, $36.5 \times 29.8 \mathrm{~cm}$.

${ }^{33}$ G 303, Johannes Lingelbach, Equestrian Portrait of a Man, oil on panel, 40 x $35.7 \mathrm{~cm}$. G 304, Johannes Lingelbach, Equestrian Portrait Queen Christina of Sweden, oil on canvas laid down on panel, 40 x $35.7 \mathrm{~cm}$.

${ }^{34}$ G 105, Isaak de Moucheron, Southern Park Landscape, oil on canvas, 69 x 57 cm; G 524, Isaak de Moucheron, Southern Park Landscape, oil on canvas, 69 x $57 \mathrm{~cm}$.

${ }^{35}$ G 374,Egbert Lievensz. van der Poel, Cottage Burning at Night, oil on panel, 46.9 x $62 \mathrm{~cm}$.

${ }^{36}$ Braunschweig, Herzog Anton Ulrich-Museum, inv. 391, Frederik de Moucheron, Italian Landscape with Cattle, oil on canvas, 68 x $80 \mathrm{~cm}$. See Seelig, "Paris und retour,"328-30 and 355, n. 173.

${ }^{37}$ Michael Willmann, Rape of Europe, 1679, oil on canvas, 86.6 x $99.2 \mathrm{~cm}$; see F. Schlie, Beschreibendes Verzeichnis der Werke älterer Meister in der Grossherzoglichen Gemälde-Gallerie zu Schwerin (Schwerin: Bärensprung, 1882), no. 1120; K. Hegner, Dokumentation der kriegsbedingt vermissten Kunstwerke des Mecklenburgischen Landesmuseums, vol. 1, Gemälde und Miniaturen, Plastische Arbeiten (Schwerin: Staatliches Museum, 1998), no. 659 (with ill).

${ }^{38}$ Jan Asselijn, Winter Landscape, oil on canvas, 66.8 x $81.5 \mathrm{~cm}$; Schlie, Verzeichnis, no. 33; and Hegner, Dokumentation, no. 8 (with ill).

${ }^{39} \mathrm{G} 2343$, Jan Brueghel the Elder, Fish Market in Front of a City on the Water, oil on copper, $18 \mathrm{x}$ $27.5 \mathrm{~cm}$.

${ }^{40} \mathrm{G} 123$, Simon de Vlieger, Calm Sea, oil on panel, 52 x $89 \mathrm{~cm}$.

${ }^{41}$ Possibly G 361, Dirck van Bergen, Landscape with Cows, oil on canvas, 35 x $47.6 \mathrm{~cm}$; or G 362, Dirck van Bergen, Farm Yard, oil on canvas, 35 x $47.6 \mathrm{~cm}$.

\section{Bibliography}

Manuscript Sources

Landeshauptarchiv, Schwerin, 2.26-2 Hofmarschallamt mit Hofbauamt [1753-1918/20], Nr. 
1849, Inventarium über die sämtlichen Zimmer, Mobilien und Gemählde auf dem Herzogl. Schlosse zu Schwerin, aufgenommen Anno 1752 Mense Januar von Notar Cuno Henning Schroeder.

Landeshauptarchiv, Schwerin, 2.12-1/26 Acta aulica, II. Etat- und Rechnungswesen, Nr. 29a.

Landeshauptarchiv Schwerin, 2.12-1/26 Acta aulica, VI. Angebote und Erwerbungen, Nr. 65 (J. N. van Haften).

Landeshauptarchiv, Schwerin, 2.12-1/26, Acta aulica, VI. Angebote und Erwerbungen, no. 101 (Gerhard Morell).

\section{Secondary Sources}

Brown, C. Carel Fabritius: Complete Edition with a "Catalogue Raisonné." Oxford: Phaidon, 1981.

Duparc, F. J., G. Seelig, and A. van Suchtelen. Carel Fabritius 1622-1654. The Hague: Mauritshuis; Schwerin: Staatliches Museum, 2004-5.

Frank, C. "Pictorial Relations: New Evidence on Jean-Baptiste Oudry and the Court of Mecklenburg-Schwerin." In Oudry's Painted Menagerie: Portraits of Exotic Animals in Eighteenth-Century Europe. Edited by M. Morton, 31-57. Los Angeles: J. Paul Getty Museum, 2007.

Giltaij, J. Senses and Sins: Dutch Painters of Daily Life in the Seventeenth Century, Rotterdam: Museum Boijmans Van Beuningen; Frankfurt am Main: Städel Museum, 2004-5.

Groth, J. G. Verzeichniß der Gemälde in der Herzoglichen Gallerie. Schwerin: Bärensprung, 1792.

Hegner, K. Dokumentation der kriegsbedingt vermissten Kunstwerke des Mecklenburgischen Landesmuseums. Vol. 1, Gemälde und Miniaturen, Plastische Arbeiten. Schwerin: Staatliches Museum, 1998.

Korthals Altes, E. “The Art Tour of Friedrich of Mecklenburg-Schwerin.” Simiolus 31 (2004-5): 216-50.

Lugt, F. Répertoire des Catalogues de Ventes Publiques, vol. 1. The Hague: Nijhoff, 1938. Manuth, V. "A Note on Carel Fabritius's Sentry in Schwerin." Oud Holland 119 (2006): 99109. http://dx.doi.org/10.1163/187501706X00375

Pincus, L. Experiment in Seventeenth-century Dutch Painting: The Art of Carel Fabritius. Ann Arbor, Mich.: UMI, 2005.

Schlie, F. Beschreibendes Verzeichnis der Werke älterer Meister in der Grossherzoglichen Gemälde-Gallerie zu Schwerin. Schwerin: Bärensprung, 1882.

Seelig, G. Jan Brueghels Antwerpen: Die flämischen Gemälde in Schwerin. Schwerin: Staatliches 
Museum, 2003.

Seelig, G. [Review] "Carel Fabritius: Symposium des Niederländischen Instituts für Kunstgeschichte (RKD) und des Mauritshuis, Den Haag, 1.-2. Dezember 2004," Kunstchronik 58 (2005): 6-11.

Seelig, G. "Paris und retour-Die Schweriner Gemäldesammlung 1807-1816." In Unter Napoleons Adler: Mecklenburg in der Franzosenzeit. Edited by M. Manke and E. Münch, 313-62. Lübeck: Schmidt-Römhild, 2009.

Seelig, G. Die holländische Genremalerei in Schwerin. Petersberg: Imhof, 2010.

Wigger, F. "Aus dem Leben Herzog Friedrichs des Frommen bis zu seinem Regierungsantritt.” Jahrbücher des Vereins für mecklenburgische Geschichte und Alterthumskunde 45 (1880): 53-176.

Recommended Citation:

Gero Seelig, "Archival Note: Gerhard Morell and the Last Acquisitions of Christian Ludwig of Mecklenburg-Schwerin," JHNA 4:1 (Winter 2012), D0I: 10.5092/jhna.2012.4.1.4 